\title{
EVALUATION OF INFORMATION AND ADOLESCENT COUNSELING CENTER MANAGEMENT TO DELAY EARLY MARRIAGE IN ADOLESCENTS IN SENIOR HIGH SCHOOL 4, JAMBI, INDONESIA
}

\author{
Muhammad Rifqi Azhary',2), Dwi Noerjoedianto'), Hubaybah1) \\ 1)Faculty of Public Health, Universitas Jambi, Indonesia \\ 2)Faculty of Medicine, Universitas Sebelas Maret
}

\begin{abstract}
Background: Teenage marriage have historically been associated with a variety of negative outcomes such as lower education levels, higher unemployment rates, worse health, lower wages and higher crime rates. Studies have revealed significant differences in most of the dimensions of marital quality, before and after marital counselling. The purpose of this study was to investigate evaluation of information and adolescent counseling center management to delay early marriage in adolescents.

Subjects and Method: This was a qualitative study with a case study approach. The study was conducted at Public Senior High School 4 Jambi, Indonesia, from January to May 2019. 10 key informants were selected for this study. The data were collected by indepth interview and observation. The data were analyzed using source, data, and method triangulations.

Results: The implementation of adolescent's guidance and counseling center services still has room for improvement. There were several factors that lack of optimal results, for example the process of members or educators recruitment and training (input aspects), planning, report and evaluation system (process aspect) and students' knowledge about health reproduction and adolescent marriage (output aspect).

Conclusion: There is a need to improve information and counseling service.

Keywords: evaluation, counseling and information center service, adolescents, delayed early marriage

Correspondence:

Muhammad Rifqi Azhary. Masters Program in Public Health, Universitas Sebelas Maret. Jl. Ir. Sutami 36A, Surakarta 57126, Central Java. Email: rifqiazhary.ra@gmail.com. Mobile: +6285363817339 .
\end{abstract}

